\title{
Correlation Between Tolerance for Disagreement and Postsecondary Enrollment Among African American Men
}

\author{
David V. Tolliver, III \\ Student Success and Advising Center, Southwest Minnesota State University \\ Individualized Learning 224D, Marshall, Minnesota 56258 \\ Tel: 1-507-537-6139 E-mail: david.tolliver@smsu.edu
}

Michael T. Miller (Corresponding author)

Higher Education Program, University of Arkansas

100 Graduate Education Building, Fayetteville, Arkansas 72701 United States

Tel: 1-479-575-3582Ｅ-mail: mtmille@uark.edu

G. David Gearhart

Higher Education Program, University of Arkansas

100 Graduate Education Building, Fayetteville, Arkansas 72701 United States

Tel: 1-416-777-7777Ｅ-mail: gdgearh@uark.ca

Received: November 23, 2020 Accepted: December 22, 2020 Published: December 27, 2020

doi: 10.5296/hrr.v4i1.17919 URL: https://doi.org/10.5296/hrr.v4i1.17919

\begin{abstract}
The study explored the concept of disagreement within family and societal structures, hypothesizing that for certain individuals to dramatically break with family and social traditions, they must have a high level of disagreement. Using McCroskey's Tolerance for Disagreement scale, the findings indicated that those African American men who were included in the study had significantly higher levels of Tolerance for Disagreement than
\end{abstract}


African American men who did not pursue postsecondary education.

Keywords: Postsecondary access, African American men, Tolerance for Disagreement, Communication measures, Social capital, Community expectancy

\section{Introduction}

Multiple efforts have been made over long periods of time to increase the enrollment of underrepresented populations in higher education. These efforts date to the founding of many institutions, with mission statements specifically tied to the enrollment and education of certain populations, including Native Americans and the 1890 land grant universities designed to offer an education to African Americans. These efforts have produced positive results in many settings, particularly noting the rise in Hispanic and Asian American enrollments in higher education.

The enrollment of African Americans in higher education has continued to be somewhat problematic. Although the number of African Americans in higher education has increased over the past 40 years, this populations increase has been lower than other underrepresented populations. Additionally, and perhaps more importantly, the number of African American men in higher education has grown more slower than other populations. For example, in 1970, NCES estimated that $20 \%$ of African American men attended some form of postsecondary education, and by 2018 that percentage had increased to about 33\%. For African American women, however, their participation in postsecondary education grew from $15 \%$ to $41 \%$ (NCES, 2018). During this same period of time, Hispanic participation in postsecondary education grew from $13 \%$ to $36 \%$. In addition to lower levels of postsecondary participation, African American students, particularly men, tend to be disproportionately represented in non-4-year institutions.

A challenge to these institutions is how they can go about increasing enrollment of African American males. Tolliver (2020) studied the issue from the perspective of family and home life, a perspective also taken by Dowe (2020). In Tolliver in particular, but alluded to by Dowe, the role of the family and home life was identified as an critically important variable in deciding to pursue a postsecondary education.

Tolliver's suggestion and finding that the family is an important element in deciding to attend college has been explored by a variety of scholars (LIST 2 OR 3 HERE), however, his research introduced the element of inter-family disagreement as a possible inhibiting variable in the decision to attend postsecondary education. Basing his study within the framework of Community Expectancy (CITE), he notes that a first-generation student might encounter resistance or even hostility from a community or family in making the decision to move away from home and a hometown to attend college. This means that an individual must have some level of willingness to challenge and disagree with those who have been caregivers to the individual in the past.

Based on Tolliver's findings that those African American men who were successful in attending and matriculating through college, the current study was designed to explore the variable of disagreement among African American men with their families. The purpose of 
the study was to identify the acceptance of disagreement among college and non-college going African American men and to identify if there is a positive correlation with accepting disagreement.

\section{Background of the Study}

A central tenet to the emerging theory of Community Expectancy is that different agencies (groups, both formal and informal) can exert a power over the identity formation of an individual. This identity formation includes the construction and foreclosure on values and moral development, meaning broadly, that a person's identity is shaped by the world in which they mature.

Tolliver (2020) noted that within a community exerting expectations and influences upon an individual, there may be a dissonance between a community and family, resulting in tension and disagreement between the youth and family (or guardians). The premise of this argument is visible and has an historic foundation in educational psychology, and is particularly noted in college student development literature that highlights emerging adults pushing back against the authority figures in their lives in order to come to independent conclusions of identity. Tolliver's argument, however, is unique in recognizing that not all familial structures might be encouraging of attending postsecondary education or finding a job or moving away from a family's hometown.

As an emerging adult questions authority, including legal, real, and perceived authority, one path might be to agree with the influencers encountered in their lives (parents, teachers, peers, local citizens, church leaders, etc.), and another might be to radically resist their ideas, values, and even life choices. This thinking typically is that these influencers want the young adult to go off to college and find a job; Tolliver suggests, however, that there are many environments and homes where the opposite is true. He notes that in some cases parents and guardians do not want the young adult to leave home, to move away to a college town, to find a life that is different from what the parents and guardians have offered to the youth.

Derden (2011) made similar observations on the contradictory roles that agencies can play in identity development. Although he found few correlations between community agencies and postsecondary enrollment, he did suggest that some variables, such as strong religious adherence, for example, might have the ability to restrict how an individual creates meaning and identity in life and subsequently, life choices such as enrolling in postsecondary education. Some religious denominations, for example, might discourage questioning of elders or doctrine, might express upon an individual certain attitudes about sexual exploration, and might even place strong gender stereotypes on the roles that women can play in society. In each of these scenarios, individuals' identity can be constructed and linked to the world around them.

Tolliver, then, attempts to argue that an individual must have a strong or high level of tolerance for disagreement within the family (or similar) environment. The concept of Tolerance for Disagreement was initially developed by McCroskey, Knutson, and Hurt (1975) and McCroskey, Richmond, and Stewart (1986), and as a communication-related trait that 
reflects an individual's ability to accept disagreement (Knutson, McCroskey, Knutson, \& Hurt, 1979). Specifically, tolerance for disagreement has been defined as "the amount of disagreement an individual can tolerate before he or she perceives the existence of conflict in a relationship" (McCroskey, Richmond, \& Stewart, 1992, p. 125).

Richmond and McCroskey (1979) first studied the concept of tolerance for disagreement as an element of organizational behavior and how individuals interact with supervisors.in an organizational setting. This communication construct eventually became caste on a scale ranging from negative interpersonal outcomes (destructive) ranging to purposeful disagreement (constructive; Teven, McCroskey, \& Richmond, 1998). The idea was further refined in an attempt to classify disagreement, where opinions differ yet something productive and helpful can arise from the encounter, to conflict, often resulting in hostility (McCroskey \& Wheeless, 1976). This range was described as balance theory, as personal affinity could move encounters and communication to either a more or less constructive encounter.

Tolerance for disagreement includes both verbal and non-verbal components of communication (Richmond, McCroskey, \& Hickson, 2007). Extreme conflict and hostility can lead to acts of violence, and this can occur in environments where individuals have high levels of interaction and knowledge of each other as well as in communication with random individuals. Martin and Rubin (1994) stressed that individuals with high tolerance for disagreement tend to have strong cognitive flexibility, meaning that they are able to understand other viewpoints and are open to differences.

If African American men are to transform their stereotypes and create opportunities for themselves, both in higher education and in professional environments, they will have to confront societal expectations of their roles. This means that they have to have the cognitive flexibility to challenge those around themselves to envision, and through work change, their postsecondary options by challenging what is expected from them. They must have a tolerance to disagree with those who might have lower expectations for their lives.

\section{Research Methods}

Data were collected using the Tolerance for Disagreement scale originally developed by McCroskey and several different colleagues. The original iteration of the scale resulted in a .90 level of reliability (Hurt \& Tiegen, 1977). Richmond and McCroskey (2001) similarly found the alpha reliability score to consistently be around .85 .

The Tolerance for Disagreement scale consists of 15 items, some of which are reverse coded. The total possible score on the scale ranges from 15 to 75 with a midpoint of 45 . Any score 46 and higher is considered to be 'high,' and any score 32 or lower is considered to be 'low.' A high score indicates that an individual has a high tolerance for disagreement, and that the individual can accept other peoples' points of view, worldview, attitudes, etc. Conversely, a low score would represent an individual who is unwilling to accept someone else's ideas, convictions, etc. (Teven, Richmond, \& McCroskey, 1998; Richmond \& McCroskey, 2001).

In addition to the 15 -items that comprised the tolerance for disagreement scale, an additional 
question was added asking the participant to identify whether or not he was attending college, did not attend college, or planned to attend college.

Three sets of African American men over the age of 18 but under the age of 30 were included in the study. The first group of 100 men were enrolled at a comprehensive, mid-western university. They were identified through the institution's multicultural center as having a membership in the African American (Black) student congress. These men received the survey in a paper form over a two-week period of time in the fall 2020 academic semester. The surveys were made available through the multicultural center, and an email message was sent to the sample of men to visit the center and fill out the survey. Completion of the survey was also encouraged by the director of the multicultural office, and at one meeting of the institution's Black student congress, the survey was made available for students to complete.

The second group, consisting of 75 African American men, were participants in a local social club targeted at young adults in a mid-western community. This social club was designed primarily to offer after-school programming for students who did not have a home or place to go after the typical school day. The 75 men identified were peer-mentors, volunteers, and symbolic 'older siblings' who had a formal, volunteer role at the club. Due to the COVID pandemic changes, these individuals had a combination of live, in-person and virtual relationships with students. The Tolerance for Disagreement instrument was described to the men in a training session, and the instrument was sent to them electronically to complete.

And the third group consisted of 48 men who were identified with a local African Methodist Episcopal Church. These men had some formal affiliation with the church, such as having participated or active participation in the church youth group. Recognizing that they were all over the age of 18, the organization was identified as a 'young adult ministry' for those who were out of high school. The 48 African American men received an email from a church official asking them to participate by completing the survey. The church also hosted several in-person events, and the attending men were asked to participate in the survey and were given an opportunity to complete the tolerance for disagreement survey in a paper-format.

The variation in tolerance for disagreement survey completion does raise concerns for possible bias related to completing the survey in person or online. The descriptive and exploratory nature of the study, however, provided a justification for accepting this limitation.

\section{Findings}

Of the 100 possible student identified at the college engaged in the study, 61 (61\%) fully completed the Tolerance for Disagreement (TFD) survey. As shown in Table 1, this group had a TFD average score of 53 which was one standard deviation higher the hypothetical midpoint, indicating that the overall group had a high tolerance for disagreement. An added question to the survey was about the respondent's intention to enroll in college. Nearly all students who were enrolled at this college indicated that "yes" they were intending to or were currently enrolled in college, resulting in a strong, positive correlation between attending college and the TFD score. Additionally, the TFD scores were separated by low (32 or lower), standard (33-45), and high (46+), and separate correlations were run for each category of 
respondent, all resulting in strong positive correlations (.999 for all three groups).

The second group of participants were the African American men from the local social club. Out of the possible 75 respondents, 44 fully completed the survey ( $58 \%$ response rate). These men, as a group, had an average TFD score of 47; a score in the "high" range, meaning a high tolerance for disagreement (range 28-55). When the scores for this group were separated by low, standard, and high, the resulting correlation with current or intended enrollment in college was strong for the "high" group ( $r=.761)$ progressing to a lower correlation of $r=.337$. These scores (see Table 1) illustrated a trend of less tolerance for disagreement being correlated with lower expectations of enrollment in college.

Table 1. Tolerance for disagreement scores and college correlation by sample location

\begin{tabular}{|l|l|l|l|}
\hline & $\begin{array}{l}\text { College students } \\
\mathrm{n}=61\end{array}$ & $\begin{array}{l}\text { Boys club } \\
\mathrm{n}=44\end{array}$ & $\begin{array}{l}\text { AME church } \\
\mathrm{n}=24\end{array}$ \\
\hline Average TFD & 53 & 47 & 32 \\
\hline Range & $44-71$ & $28-55$ & $19-48$ \\
\hline$r 1$ & .999 & .761 & .500 \\
\hline$r 2$ & .999 & .503 & .228 \\
\hline$r 3$ & .999 & .337 & .099 \\
\hline
\end{tabular}

The third group of participants, those affiliated with a local church youth group, had an overall group TFD average score of 32 , the base score for the category of "low" tolerance for disagreement (range 19-48). The scores for the group, when considering TFD level and college had correlations of $r=.500, r=.228$, and $r=.099$, meaning there was a very low correlation between the individuals with low TFD and the expectation of attending college.

\section{Discussion}

The findings of the current study demonstrate a positive correlation between tolerance for disagreement and attending postsecondary education for African American men. This broadly means that those men who decide to continue their education are accepting a level of disagreement most likely in their home life about the decisions they make to attend college. The positive correlation provides some support for the ideas advanced by Tolliver and the emerging theory of Community Expectancy, among many others, that contend that the power of the family, home life, peers, and society can strongly influence what a young person decides to view as acceptable.

The power of informal influences can be substantial, and the identification of these actors in 
the identity formation process can be critical in the public sphere in discussions and setting an agenda to create a more equitable society. These types of influences might be playing a significant role in the sustaining of generational poverty, and the ability to isolate informal actors that pressure an individual might result in breaking these cyclical tendencies. From a practical perspective, this means that programs, policies, and efforts that are targeted at late-youth are probably already too late to make a meaningful change in a person's identity. These interventions need to be structured so that the young person has a level of exposure to ideas about tolerating differences early in the identity development process, and more than likely, such interventions would be framed around public education.

In addition to efforts developed through public education, the study findings stress the need for positive home life environments where parents or guardians are supportive of their children on a conscious and sub-conscious level. This means that not only do they have to be openly supportive of their children charting their own directions, but that their actions, behaviors, and values need to align with the language of allowing their children to be different than themselves. This kind of thinking that might encourage parents to allow their children to be 'different' might mean that they need exposure, discussion, education, and even training about parenthood or guardianship that extends beyond basic care of infants.

Additional programming might be considered in the public realm that supports young people in exploring who they are and who they want to become. These cannot be restricted just to public education, although those schools can be a highly influential venue for experimentation and exploration, and need to include influential community actors and agencies that have different touchstones in a person's life development.

Ultimately, public agendas need to recognize that identity formation at a very early age can result in an individual's decision to remain enrolled in school and to pursue different postsecondary options. That means that there have to be meaningful, constructive, and significant interventions and propelling interjections into communities about the powerful outcomes that can come from a continued education or meaningful job training.

\section{Conclusion}

Individual identity can lead a person to make decisions and choices based on what they see value in. For the African American men in this study, those who enrolled in college or intended to enroll in college had high levels of tolerance for disagreement, meaning, they were able to frame what they wanted (presumably further education and its benefits) against expectations of themselves by others.

\section{References}

Derden, M. W. (2011). Community expectations of college attendance and completion. Unpublished doctoral dissertation, University of Arkansas, Fayetteville, AR.

Dowe, A., Jr. (2020). Program evaluation for the Attracting Intelligent Minds conference at the University of Arkansas. Unpublished doctoral dissertation, University of Arkansas, Fayetteville, AR. 


\section{I Macrothink}

Hurt, H. T., \& Teigen, C. W. (1977). The development of a measure of perceived organizational innovativeness. In B. R. Ruben (Ed.), Communication Yearbook I (pp. 377-385). New Brunswick, NJ: Transaction Books. https://doi.org/10.1080/23808985. 1977.11923693

Knutson, P. K., McCroskey, J. C., Knutson, T., \& Hurt, H. (1979, February). Tolerance for disagreement: Interpersonal conflict re-conceptualized. Paper presented at the Annual Convension of the Western Speech Communication Association, Los Angeles, CA.

Martin, M. M., \& Rubin, R. B. (1994). Development of a communication flexibility scale. Southern Communication Journal, 59, 171-178. https://doi.org/10.1080/10417949409372934

McCroskey, J. C., Knutson, T. J., \& Hurt, H. T. (1975). New perspectives on conflict management. Panel presentation at the annual convention of the West Virginia Speech Association, Morgantown, WV.

McCroskey, J. C., Richmond, V. P. Stewart, R. A. (1986). One on one: the foundations of interpersonal communication. (1st ed.). Englewood Cliffs, NJ: Prentice-Hall.

McCroskey, J. C., Richmond, V. P., \& Stewart, R. A. (1992). One to one: The foundations of interpersonal communication (2nd ed.). Englewood Cliffs, NJ: Prentice Hall.

McCroskey, J. C., \& Wheeless, L. R. (1976). Introduction to human communication. Boston, MA: Pearson/Allyn and Bacon.

National Center for Education Statistics. (2018). Percentage of 18-to 24-year-olds enrolled in college, by level of institution and sex and race/ethnicity of student: 1970 through 2018. Washington, DC: Author. Retrieved online at https://nces.ed.gov/programs/digest/d19/tables/dt19_302.60asp

Richmond, V. P., \& McCroskey, J. C. (1979) Management communication style, tolerance for disagreement, and innovativeness as predictors of employee satisfaction: A comparison of single-factor, two-factor, and multiple-factor approaches. Annals of the International Communication Association, 3(1), 359-373. https://doi.org/10.1080/23808985.1979. 11923771

Richmond, V. P., \& McCroskey, J. C. (2001). Organizational communication for survival: Making work, work ( $2^{\text {nd }}$ Ed.) Needham Heights, MA: Allyn \& Bacon.

Richmond, V. P., McCroskey, J. C., \& Hickson, M. L. (2007). Nonverbal behavior in interpersonal relations (6th ed.). Boston, MA: Pearson/Allyn \& Bacon.

Teven, J. J., Richmond, V. P., \& McCroskey, J. C. (1998). Measuring tolerance for disagreement. Communication Research Reports, 15, 209-217. https://doi.org/10.1080/ 08824099809362115

Tolliver, D. V., III. (2020). The development and postsecondary enrollment of Black American men: The perceived influence of environmental factors. Unpublished doctoral dissertation, University of Arkansas, Fayetteville, AR. 


\section{Macrothink}

Human Resource Research

ISSN 1948-5441

2020, Vol. 4, No. 1

\section{Copyright Disclaimer}

Copyright for this article is retained by the author(s), with first publication rights granted to the journal.

This is an open-access article distributed under the terms and conditions of the Creative Commons Attribution license (http://creativecommons.org/licenses/by/3.0/). 